\title{
The Integration of Palm-Beef Cattle as a New Opportunities in New Normal
}

\author{
Rachma Bhakti Utami*, A. Miftakhul Khoiri, Restu Mulya Pratama, Mochamad Agung Prawiro \\ SmartID \\ Institute for Development and Governance Studies \\ Malang, Indonesia \\ *rachmabhaktiutami@gmail.com
}

\begin{abstract}
This study examines the potential investment and utilization of existing resources in integrating palm - beef cattle as a new opportunity in the new normal. It analyzed the study's primary data using cost and financial analysts such as; Net Present Value, Internal Rate of Return, Net Benefit/ Cost Ratio, Payback Period, and Break Event Point to calculate the feasibility of investing. This research takes location in Lamandau, Central Kalimantan, and develops another palm to reduce the cost component and optimize investment. This study indicates that beef cattle's investment and the integration of beef cattle palm is feasible. This study showed that it could explore many potentials in an area and collaborate and use existing resources as a new strategy to maintain business resilience in the new normal. This study informs that beef cattle and the integration of beef cattle - palm can be a business solution and applied to Indonesia's other regions.
\end{abstract}

Keywords-investment, integration of palm - beef cattles, new opportunities, new normal

\section{INTRODUCTION}

By-Law Number 5 of 2002 concerning the Establishment of Regencies in Central Kalimantan Province, Lamandau Regency is one of the areas resulting from the Kotawaringin Barat district's division. Lamandau Regency, as a newly created autonomous region, has the authority to manage its natural wealth and human resources. The Lamandau Government, consisting of 8 Districts, seeks to optimize and synergize all the potential in Lamandau Regency to meet the needs and create welfare for the people of Lamandau Regency.

The efforts that can be made in developing investments that can attract investors to develop the potential of Natural Resources into a particular industry, both semi-finished and finished goods. To synergize the increase in regional economic growth supported by increasing local investment, the Lamandau Regency Government needs to prepare several measures such as regulations, infrastructure, climate, and investment security conducive to encouraging the increasing number of investors who invest their capital.

Investment is one of the essential factors determining the success of economic development. The existence of investment is the necessary capital for the realization of sustainable economic growth. In that case, the investment will increase supply through an increase in capital stock, which will increase the production sector to produce output or carry out production activities [1]. This production activity will increase the absorption of labor, and this process will ultimately increase economic growth. This economic growth can be achieved by growing investors who invest in Lamadau Regency.

According to data from the Lamandau Regency Investment Service and One-Stop Integrated Service (DPMPTSP), the total value of the realized foreign investment in Lamandau Regency in 2013 was Rp. 650,719,519,193, and this number lasted until 2014. Then in 2015, the amount of realized value of foreign direct investment increased to Rp. 825,814,041,495, and in 2016 it increased again to Rp. 1,567,397,857,798 ,. However, in 2017 it decreased to Rp. 1,564,530,989,112, this number lasted until 2018. Based on these data, we can see it tends to increase in terms of the amount of realized value of foreign investment in the Lamandau Regency, even though it has decreased in 2017 and 2018. Unlike the case with the number of realization of PMDN investment in Lamandau Regency, which always increased from 2013 to 2018, can see it from 2013, the amount of realized PMDN investment in Lamandau Regency was Rp. 2,085,220,686,868, then continued to increase until in 2018 it touched Rp. 7,571,542,268,699 (Figure $1)$

Total Realized Value of PMA and PMDN Investments

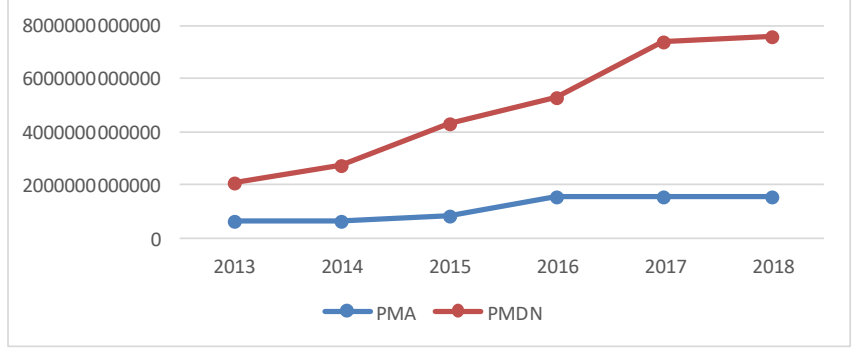

Source: Author's Process, 2020

Fig. 1. Realization of PMA and PMDN in Lamandau Regency 2013-2018. 
From this data, the Lamandau Regency government seeks to continue to optimize natural resources and superior products from various sectors ranging from agriculture, plantation, fishery, mining products. The Lamandau Regency can maintain foreign investment and PMDN, utilizing implementing a system that can attract investors' attention to investing in Lamandau Regency.

In the book Study of Potential and Regional Investment Development Profiles in Lamandau Regency, published by the Investment Service and One Stop Services (DPMPTSP) of Lamandau Regency, it is stated that the tourism sector is the leading sector. Based on the mapping of leading sectors based on PDRB with the calculation of shift-share, LQ, Tipoligi Klasen, and FGD from various parties, the tourism sector is superior, with various tourist destinations including Bukit Lubang Kilat, Susur Desa, Begondong Procession, Education Matting, and different other tourist locations.

The Covid-19 pandemic condition that has hit the entire world has caused economic shocks, especially in the tourism sector. In the publication of COVID-19 and tourism issued by the United Nations Conference on Trade and Development, by the end of the first quarter of 2020, the COVID-19 pandemic had brought international travel to an abrupt halt and significantly impacted the tourism industry. For many developed and developing countries, the tourism sector is a significant source of employment, government revenue, and foreign exchange earnings. Without this vital lifeline, many countries may experience a dramatic contraction in GDP and a rise in unemployment [2]

Lamandau Regency itself is trying to respond to the effects of the Covid-19 pandemic. The Lamandau Regency Government, through the Investment Service and One-Stop Integrated Service (DPMPTSP), is promoting another sector as an alternative to new opportunities, namely the integration of Cattle-Palm Oil as a superior regional commodity. As is known, Lamandau is an area with abundant oil palm land. Data from BPS states that the total oil palm plantations in Lamandau Regency as of 2018 are 30,074.79 hectares. Meanwhile, from the number of cattle population, data from Lamandau Regency in the figures show that from 2016 to 2019 (figure 2), the cattle population is quite volatile but shows an increasing trend. On the other hand, the level of protein consumption of the people of Lamandau Regency for meat consumption also continues to increase. According to the 2018 Animal Husbandry and Animal Health Statistics, per capita beef consumption in 2017 was $0.469 \mathrm{~kg}$ or 12.50 percent from the 2016 per capita beef consumption of $0.417 \mathrm{~kg}$.

Meanwhile, in Lamandau Regency itself, the average daily consumption of calories and protein per capita according to the food group shows that meat consumption is 6.84 grams a day, the third-highest after grains and fish. From the background mentioned and the three reasons, the integration of cattle-oil palm is a new investment opportunity for the Lamandau Regency Government.

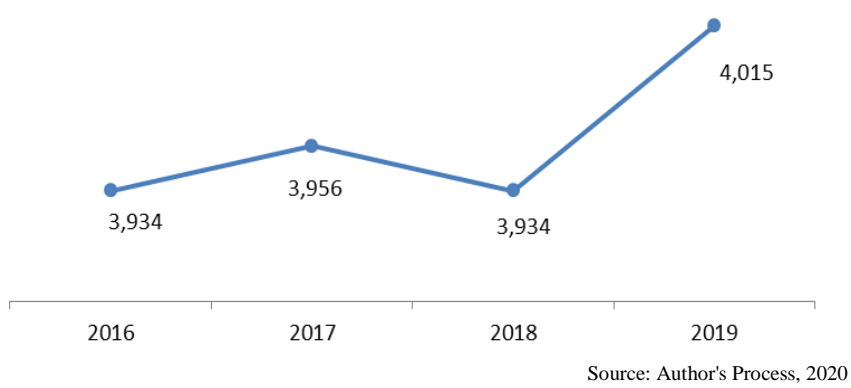

Fig. 2. Beef Cattle Population, 2016-2019 Lamandau, Regency.

\section{THEORETICAL BASIS}

\section{A. Regional Economic Development}

1) Definition of regional economic development: Regional Economic Development, according to Todaro [3], is defined as a multidimensional process that includes changes in social structures, people's attitudes to life, and national institutions Besides, the development consists of economic growth changes, reducing national income inequality, and eradicating poverty. A country's story can be directed at three main things: improving the community's welfare and increasing the community's ability to access economic activities and social activities in their lives.

According to Ananda [4], regional economic development can be interpreted to improve using public resources available in the region. Therefore, regional economic development is meant to be a process where there is a collaboration between local governments and communities in managing existing resources.

\section{2) Regional economic development theory}

a) Economic basis theory: This theory of the regional economy is divided into two, namely: necessary activities and non-basic activities. Essential activities are activities that export goods and services beyond the boundaries of the community's economy. Meanwhile, activities that are not basic are activities that only provide goods and services needed by people who live within the community's economic boundaries, so the market area is only local [4].

b) Growth pole theory (growth pole theory): The places or areas that are the centers of development are called growth centers or poles. Perroux put forward this theory in 1955. The development process originating from the growth center pole will spread to other regions around it. This theory aims to increase investment in certain areas so that the regional economy can improve and produce a positive multiplier effect on the economy. 


\section{B. Investments}

Investment has an essential role in a country's economy. According to the theory of the multiplier initiated by Keynes discusses the influence of the government budget on economic growth, to influence the economy's course, the government can increase expenditure budget in the sluggish financial situation (recession) employment and real income communities will be increased.

\section{Financial Feasibility Study}

There is information other than the estimated investment size that needs to be included as a complement, namely information related to financial analysis or financial feasibility analysis. Financial feasibility analysis is studied through cost and benefit analysis, profit and loss analysis, investment criteria analysis. Financial feasibility includes Net Present Value (NPV), Internal Rate Return (IRR), Net Benefit-Cost Ratio (Net B / C Ratio), Payback Period (Gittinger) [5] and Break-Even Point [6].

\section{METHODOLOGY}

This study uses descriptive research with a quantitative approach. The quantitative approach uses investment feasibility analysis and cost and financial analysis. There is information other than the estimated investment size that needs to be included as a complement, namely information related to financial analysis or financial feasibility analysis. Financial feasibility analysis is studied through cost and benefit analysis, profit and loss analysis, investment criteria analysis. Financial feasibility includes Net Present Value (NPV), Internal Rate Return (IRR), Net Benefit-Cost Ratio (Net B / C Ratio), Payback Period (Gittinger) [5] and Break-Even Point [6].

\section{A. Net Present Value (NPV)}

Net present value (NPV) is the difference between the total present value of benefits and the total present value of costs or the sum of the present value of net benefits over the business [7]. NPV shows the company's net benefits over the life of the business at a specific discount rate. The unit of NPV is Rupiah. A business is said to be feasible if its NPV value is greater than zero, while a business whose NPV value is less than zero is said to be unfit. Mathematically, the NPV is formulated as follows [7]:

$$
\mathrm{NPV}=\sum_{t=1}^{n} \frac{B t-C t}{(1+i)^{t}}
$$

\section{Explanation:}

$\mathrm{Bt}=$ Benefits in year $\mathrm{t}$

$\mathrm{Ct}=$ Cost in year $\mathrm{t}$

$\mathrm{t}=$ year of business activity

$\mathrm{i}=$ The discount rate $(\%)$

\section{B. Internal Rate Return (IRR)}

Internal Rate of Return (IRR) is an investment appraisal criterion to see the number of business returns on investment made [7]. A business is said to be feasible if the IRR value is greater than the value of the discount rate. IRR is expressed in the percentage of units (\%). Mathematically, IRR is formulated as follows [7]:

$$
\operatorname{IRR}=i_{1}+\frac{\mathrm{NPV}_{1}}{\mathrm{NPV}_{1}-\mathrm{NPV}_{2}} \times\left(i_{2}-i_{1}\right)
$$

Explanation:

$$
\begin{aligned}
& \text { NPV1 = positive NPV } \\
& \text { NPV2 = negative NPV } \\
& \mathrm{i} 1=\text { discount rate that results in a positive NPV } \\
& \mathrm{i} 2=\text { discount rate, which results in a negative NPV }
\end{aligned}
$$

IRR is a discount rate that results in NPV equal to zero. The percentage of IRR in the evaluation criteria for certain business investments is the discount rate when the NPV shows zero [7].

\section{Net Benefit-Cost Ratio (Net B/C Ratio)}

The net benefit-cost ratio (Net $B / C$ ) is one of the investment appraisal criteria to describe the net beneficial benefits for each business's unit loss [7]. A company is feasible if the Net B / C value is more than one, whereas if the Net B / $\mathrm{C}$ value is less than one, then the business is said to be unfeasible. Mathematically, Net B / C is formulated as follows [7]:

$$
\text { Net } \frac{B}{C}=\frac{\sum_{t=1}^{n} \frac{B t-C t}{(1+i)^{t}}}{\sum_{t=1}^{n} \frac{B t-C t}{(1+i)^{t}}} \cdots \frac{(\text { for } B t-C t>0)}{(\text { for } B t-C t<0)}
$$

$$
\begin{aligned}
& \text { Explanation: } \\
& \begin{array}{ll}
\mathrm{Bt} & =\text { Benefits in year } \mathrm{t} \\
\mathrm{Ct} & =\text { Cost in year } \mathrm{t} \\
\mathrm{t} & =\text { year of business activity } \\
\mathrm{i} & =\text { The discount rate }(\%)
\end{array}
\end{aligned}
$$

\section{Payback Period (PP)}

The payback period $(P P)$ is an investment appraisal criterion used to measure how quickly investment activities carried out in business can return [7]. A company can be feasible if the payback period is less than the business's age being run. The unit of the payback period is the year. Mathematically, the payback period is formulated as follows [7]:

$$
\text { Payback Period }=\frac{\mathrm{I}}{\mathrm{Ab}}
$$

Explanation:

I = Investment costs incurred

$\mathrm{Ab}=$ net benefits obtained each year 


\section{E. Break-Even Point (BEP)}

The Break-Even Point (BEP) is used to determine the relationship between variables in the company's activities, namely production costs, production volume, and company profits. BEP itself is divided into BEP based on price and BEP based on the number of units. The mathematical BEP formula used refers to Riyanto as in the following equation [8]:

$$
\mathrm{BEP}(\text { Price } / \mathrm{Rp})=\frac{\text { Fixed cost }}{1-\frac{\text { Variable cost }}{\text { price per units }}}
$$

$$
\text { BEP }(\text { Number } / \text { Unit })=\frac{\text { Fixed cost }}{\text { Variable cost }- \text { Price per unit }}
$$

\section{RESULTS AND DISCUSSION}

\section{A. Overview of Lamandau Regency}

Lamandau Regency is a district located in Central Kalimantan Province. It is a district resulting from the expansion of the West Kotawaringin Regency, which is based on Law Number 5 of 2002 concerning the Establishment of Katingan Regency, Seruyan Regency, Sukamara Regency, Lamandau Regency, Gunung Mas Regency, Pulang Pisau Regency, Murung Raya Regency, and East Barito Regency in Central Kalimantan Province.

Gross Regional Domestic Product (PDRB) cannot be separated from domestic products and local products (figure 3 ). Household products are all goods and services resulting from economic activities operating in the domestic area, regardless of whether the production factor comes from or is owned by residents of the area. It remains the domestic product of the region concerned [9].

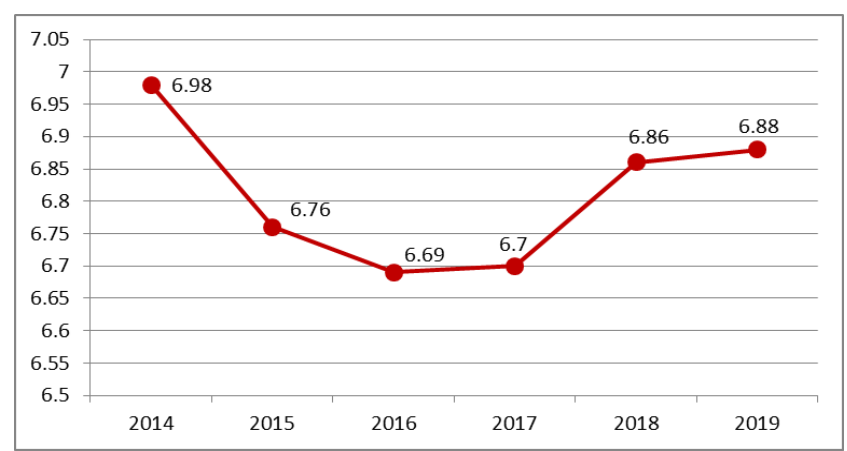

Fig. 3. Growth rate of GRDP [10].

\section{B. Investation in Beef Cattle}

Based on the type, livestock is grouped into large livestock (beef cattle, dairy cows, buffaloes, and horses), small livestock (goats, sheep, and pigs). Poultry (domestic chickens, laying hens, broilers, ducks and ducks. manila), and various livestock (rabbits, quails, and pigeons). The livestock population is the collection or number of livestock that live in a specific area and time. Based on the data presented in Figure 4, it can be seen that nationally the total population of beef cattle and dairy cows in 2018 has increased compared to the population in 2017. Still, for buffalo and horses, it has decreased.

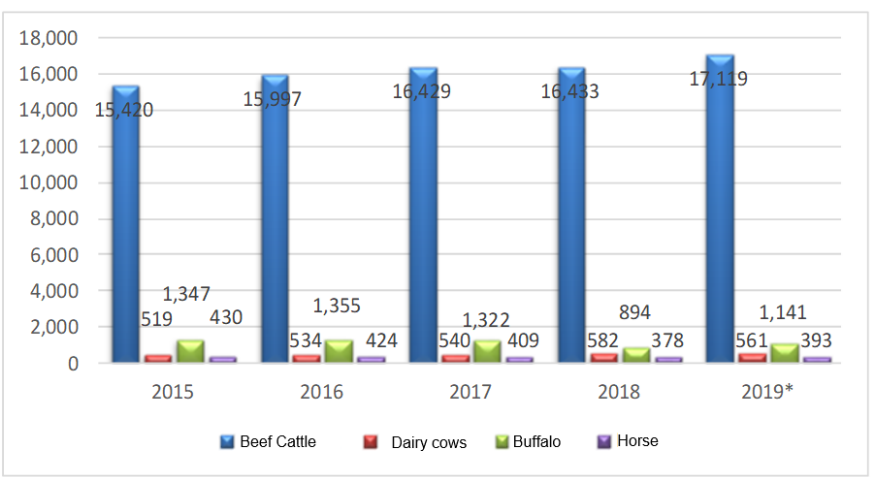

Fig. 4. FLarge livestock population [11]

The details of the livestock population are beef cattle 16.4 million heads (an increase of 0.02 percent), dairy cows 0.6 million heads (a rise of 7.66 percent), buffalo 0.9 million heads (a decrease of 32.35 percent), and horses with 0.4 million heads (a reduction of 7.62 percent). Meanwhile, the national small livestock population in 2018 experienced an increase in population compared to 2017, except for pigs, with the following details: 18.3 million goats (a rise of 0.54 percent), 17.6 million sheep (an increase of 274 percent), and 8.3 million pigs (a drop of 0.08 percent).

\section{Beef Cattle Population Per District in Kab. Lamandau}

The condition of developing the beef cattle population in the district, Lamandau, continues to increase from 2016 to 2019. Table 1 below shows the population of cattle by subdistrict in Lamandau Regency.

TABLE I. POPUlation OF CATtLE By Districts IN KAB. LAMANDAU [12]

\begin{tabular}{|c|l|l|l|l|}
\hline & \multicolumn{1}{|c|}{$\mathbf{2 0 0 9}$} & $\mathbf{2 0 1 8}$ & $\mathbf{2 0 1 7}$ & $\mathbf{2 0 1 6}$ \\
\hline Bulik & 677 & 1069 & 1172 & 1069 \\
\hline Sematu Jaya & 306 & 896 & 915 & 296 \\
\hline Menthobi Raya & 319 & 490 & 490 & 490 \\
\hline Bulik Timur & 1846 & 340 & 361 & 340 \\
\hline Lamandau & 221 & 318 & 240 & 318 \\
\hline Belantikan Raya & 157 & 209 & 282 & 209 \\
\hline Delang & 298 & 450 & 341 & 450 \\
\hline Batangkawa & 191 & 162 & 155 & 162 \\
\hline & 4015 & 3934 & 3956 & 3934 \\
\hline
\end{tabular}

\section{Analysis of Livestock Sector Industry Trees}

The potential that exists in the regions must be processed and developed into opportunities. It means that potential data derived from sector analysis, superior products, or regional development plans must be processed or analyzed again into opportunities. Opportunity for whom? Of course, it is an opportunity for investors to invest in the regions. 
Analysis can use the Industrial Tree Analysis, where a specific commodity or product develops downstream. For example, the Figure 5 below shows a Cow industrial tree.

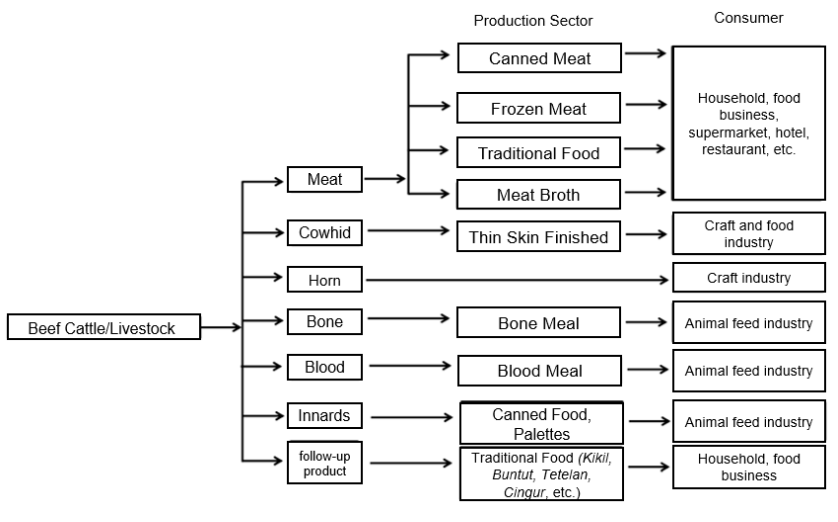

Source: Investment Coordinating Board, processed by researchers, 2020

Fig. 5. Tree cattle industry.

From the figure 5, it can be seen that the part (box) that does not exist or not many are involved in the industry/business, it can be said that this is where the opportunity arises. For example, no industry/business processes cowhide into thin, processed leather for the next industry (crafts, shoes). If there are enough cows to build a business/leather processing industry in an area, you can say that this is the opportunity. For example, in certain areas, others have not yet developed meat processing into sausages and meatballs, so the opportunity lies in this scope. Furthermore, these opportunities can be further explored using a preliminary feasibility study (Pre-Feasibility Study) to get an approximate picture of how much investment is needed.

TABLE II. RESUlts of Bef CATtLE CULTIVATION Cost ANALysis

\begin{tabular}{|l|l|l|l|}
\hline \multicolumn{1}{|c|}{ Criteria } & \multicolumn{1}{c|}{ Result of DF 14,92\% } & \multicolumn{1}{c|}{ Investment Criteria } \\
\hline NPV & $854,432,589$ & rupiah & Well worth it \\
\hline Net B / C & 1.54 & time & Well worth it \\
\hline IRR & $25.56 \%$ & percent & Well worth it \\
\hline PP & 5.35 & $\begin{array}{l}5 \text { years } 3 \\
\text { months }\end{array}$ & Well worth it \\
\hline BEP price & $342,413,907$ & rupiah & Well worth it \\
\hline BEP unit & 22.83 & tail & Well worth it \\
\hline \multicolumn{4}{|c}{ Source: Processed by Researcher, 2020 }
\end{tabular}

From the calculation of the cost and financial analysis (table 2), it can be concluded that:

- The NPV value is Rp. 854,432,589, - indicates that investment in beef cattle cultivation is feasible. Investment feasibility using the Net Present Value (NPV) method of beef cattle culture shows Rp. $854,432,589$ - is the net profit obtained at the end of a project or investment work. The net gain is calculated from the difference between the present value of the investment and the expected net cash flows from projects or investments in the future or a specific period. $\mathrm{NPV}>0$, then the asset or project is considered not feasible because it risks experiencing losses.
- The Net B / C value is 1.54 times. After calculating the NPV, the subsequent analysis that can be carried out on an investment's feasibility is the Net Benefit-Cost Ratio. Net B / C is the value of benefits obtained from a project or business every time we spend one rupiah for the project or company. Net B / C is the ratio between positive NPV and negative NPV. The calculations show that Net B / C> 1 means that this beef cattle cultivation project or business is financially feasible.

- From the calculation result, the IRR value is $25.56 \%$. The Internal Rate of Return (IRR) method measures an investment's feasibility based on an interest rate that can make the present value of the expected profit equal to the current value of the cost of capital $(\mathrm{NPV}=0)$. In this method, the time value of money is calculated so that the cash flows received are discounted based on the cost of capital or the interest rate applied.

- By using the assumption of a Discount Factor of $14.92 \%$, which is the nominal base rate of Bank Kalteng's interest, an IRR of $25.56 \%$, which is greater than the current interest rate, indicates that the investment in beef cattle cultivation is considered feasible.

- The payback period (PP) of beef cattle cultivation investment is 5.35 months. If the NPV measures an investment from its profitability, the Payback Period method measures the speed of return on investment. Therefore, the resulting unit of measure is not in the form of a percentage of rupiah, but in time. If the PBP value is faster or shorter than required, it means that the investment is feasible. Conversely, if the PBP value is slower or longer, it means that it indicates an investment is not feasible. The investment assumption for this beef cattle cultivation is 6 years, considering that its economic value is 6 years. The PP value from the calculation results is 5.35 months or faster than the investment period. Investment in beef cattle cultivation using PP analysis can be said to be feasible.

- From the calculation of the Break-Even Point (BEP), there are 2 (two) BEPs calculated, namely the BEP unit and the BEP price. From the results of the calculation of the BEP unit, it shows the number 22.83 head / we round it to 23 heads. It shows that investors must be able to sell at least 23 cows do not suffer losses. While the BEP price is Rp. $342,413,907$, - this shows that to get the break-even point with a sales price of Rp. 15 million / cow, the company must get a sales value of Rp. 342,413,907, - to break even.

- Cost and Financial Analysis calculation assumptions:

1. The initial investment value is Rp. $1 \mathrm{~m}$

2. Purchase of female cows aged 6 months, for Rp. $12,500,000,-/$ cow with the initial cow as many as 15 cows. 
3. The investment period is 6 years, assuming the economic age of the cattle is 6 years.

4. There are no additional breeders during the 6-year investment.

5. The location of the stable is rent, with an area of 1 hectare with a rental price of Rp. 30 million / year

6. Investors don't build their stables.

7. Fattening is carried out for $\pm 3-4$ months so that can felt the income from new sales in the second year

8. Sales are assumed to be $80 \%$ of the total cattle.

9. Discount Factor (DF) uses the Central Bank base rate, which is $14.92 \%$ / year.

10. Depreciation of unsold cows, using the Straight Line Method / Straight Line Method, namely:

Depreciation per year $=$ Purchase Value - Value of Remaining Economic Life

11. Income tax used is based on Law of the Republic of Indonesia Number 36 of 2008, article 17 paragraph 2a, which is the fourth amendment to Law Number 7 of 1983 concerning income tax, which is 25 percent, applies flat until the end of the business.

\section{E. Cattle-Oil Palm Integration as a New Opportunity}

As explained in the chapter on potential investment in Beef Cattle Cultivation, the advantage that Lamandau Regency has, which is considered to attract potential investors, is the availability of abundant oil palm land in this area. Besides, cake, reliable, and palm leaves derived from palm products can be processed and improve the quality of feed from cattle. It is hoped that there will be a policy from the Lamandau Regency Government to simplify and legalize the licensing for the integration of Cattle - Oil Palm so that many cattle breeders can breed their cows in oil palm locations. With this cow - oil palm integration, cattle breeders can reduce land rental costs and minimize animal feed costs to increase the potential return on investment in cattle cultivation.

\section{CONCLUSION}

Based on the study results, beef cattle cultivation is a viable investment potential from Lamandau Regency. Lamandau has much land potential, much palm oil potential, so that cow-oil palm integration can be carried out to support the potential for beef cattle cultivation. Based on the financial analysis, the potential net profit from investing in Beef Cattle Cultivation at the end of the investment period is approximate Rp. 854 million. The value of benefits obtained from each cost incurred on investment in beef cattle cultivation is 1.54 times, which shows that based on the Net B / C value above 1, it means that it is feasible to do so. Based on the IRR analysis calculation, cattle cultivation's potential investment shows a figure of $25.56 \%$. This value is above the base rate $\%$ of the standard bank interest in Kab. Lamandau. It shows that investment in beef cattle cultivation is profitable. Meanwhile, the Break-Even Point (BEP) unit value is 22.83 cows.

Investment is one of the essential factors determining the success of economic development. The existence of investment is the necessary capital for the realization of sustainable economic growth. To support a conducive investment climate, the Lamandau Regency government needs to prepare several things, including the Potential and Profile of Regional Investment Development, regulatory frameworks, support for licensing service innovation, and investment security. Investors very much need the Regional Investment Profile Book as a guideline for determining the investment feasibility. The investment feasibility calculation uses NPV, Net B / C, PP, IRR, and BEP. From all the investment feasibility estimates, beef cattle cultivation integrated with palm oil is feasible to become an investment commodity.

\section{REFERENCES}

[1] Bappenas, 2007.

[2] United Nations Development Programme, No Title. 2020.

[3] M.P. Todaro and S.C. Smith, "Economic Development Pearson Education Limited," Essex. Engl., vol. 7, 2000.

[4] C.F. Ananda, Pembangunan ekonomi daerah: dinamika dan strategi pembangunan. Universitas Brawijaya Press, 2018.

[5] J.P. Gittinger, "Analisa Ekonomi Proyek-Proyek Pertanian. Terjemahan. Edisi Kedua.” UI-Press dan John Hopkins. Jakarta, 2008.

[6] N. Diatmojo, "Analisis finansial usaha penggemukan sapi peranakan Friesian Holstein (PFH) jantan di Kec. Selo Kabupaten Boyolali,” 2012.

[7] K.A. Nurmalina R, Sarianti T, Studi Kelayakan Bisnis. Bogor: Unit Penerbit Departemen Agribisnis Fakultas Ekonomi dan Manajemen Institut Pertanian Bogor, 2010.

[8] B. Riyanto, "Dasar-dasar pembelanjaan perusahaan edisi 4," Yogyakarta Bpfe, 2001

[9] Central Statistics Agency, Central Statistics Agency, 2019. 2019.

[10] BPS Lamandau Regency, BPS Lamandau Regency, 2020. 2020.

[11] Stattik Peternakan dan Kesehatan Hewan, No Title. 2019.

[12] Lamandau Regency in Figures, No Title. 2020. 